Supplement of Atmos. Chem. Phys., 15, 6535-6548, 2015

http://www.atmos-chem-phys.net/15/6535/2015/

doi:10.5194/acp-15-6535-2015-supplement

(C) Author(s) 2015. CC Attribution 3.0 License.

(c) (i)

Supplement of

\title{
Impact of interannual variations in sources of insoluble aerosol species on orographic precipitation over California's central Sierra Nevada
}

J. M. Creamean et al.

Correspondence to: K. A. Prather (kprather@ucsd.edu)

The copyright of individual parts of the supplement might differ from the CC-BY 3.0 licence. 

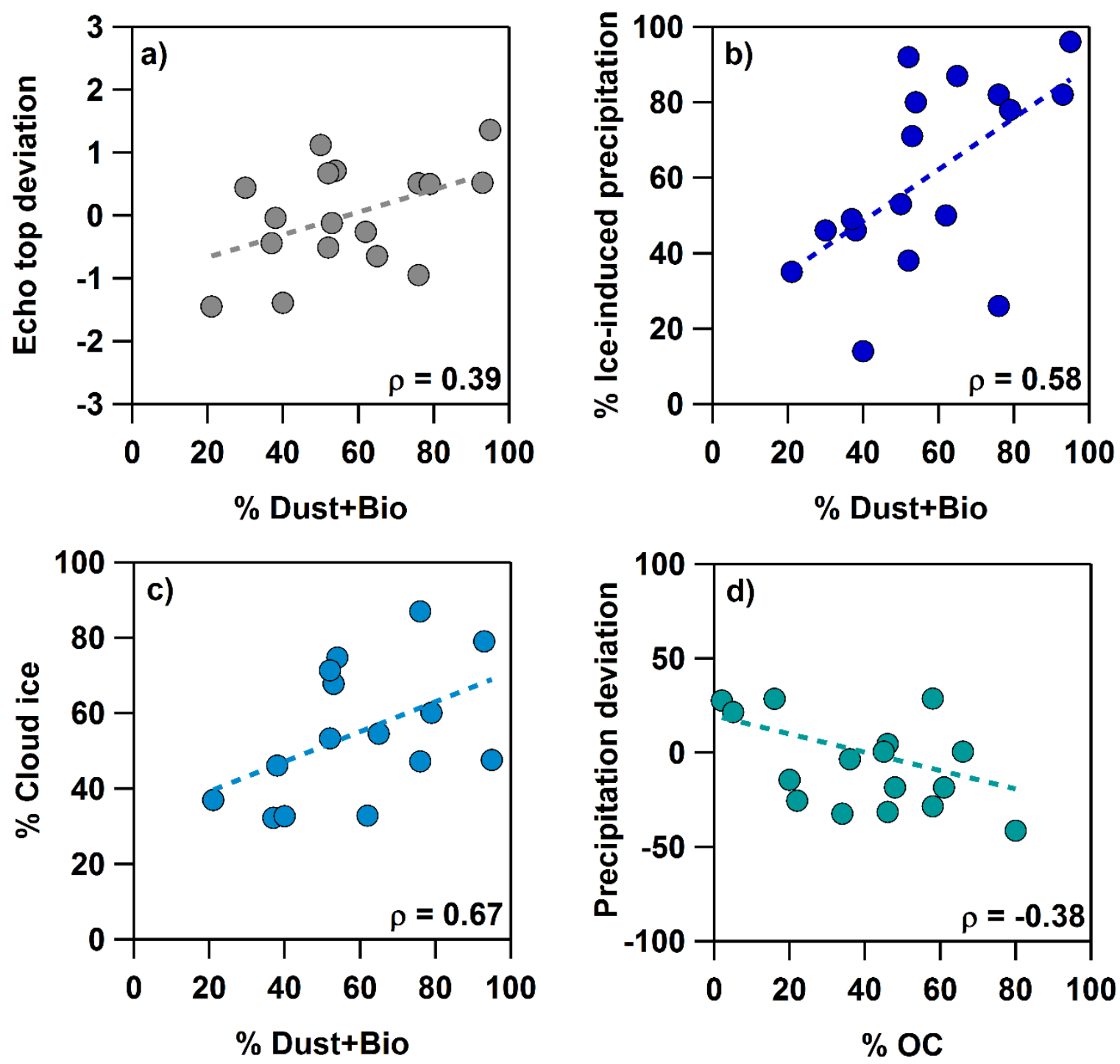

Figure S1. Correlation plots of a) echo top height deviation $(\mathrm{km})$ versus \% Dust+Bio, b) \% iceinduced precipitation versus \% Dust+Bio, c) \% cloud ice versus \% Dust+Bio, and d) precipitation deviation (mm) versus \% OC residues (pollution plus biomass burning). Also shown are the Spearman's correlation coefficients for each correlation. 